Serhat Ata,

Ph.D., Duzce University, Turkey

ORCID ID, 0000-0002-5423-5118

email:serhatata@duzce.edu.tr

Abdulaziz Sezer,

Duzce University, Turkey

ORCID ID, 0000-0001-5666-3979

email: abdulazizsezer@duzce.edu.tr

Correspondence author: serhatata@duzce.edu.tr

\title{
EVALUATING THE EFFECTS OF LIFE SATISFACTION ON IMPULSE BUYING BEHAVIOR IN TERMS OF ONLINE BUYING
}

\begin{abstract}
Consumer behaviours have great importance for marketers. Impulse buying, which is an appearance of consumer behaviour, arises with a sudden stimulus. Different aspects affect impulse buying. Life satisfaction, which is one of these aspects, brings consumers about impulse buying behaviour by influencing them. Moreover, the rapid development of online shopping and the fact that online interaction occurs in virtual environments at all hours of the day affects people's quality of life. This study aimed to investigate how consumers' life satisfaction shapes consumers' impulse buying behaviour and whether there is a difference between the descriptive and main variables in line with this relationship according to consumers' online or offline purchasing behaviour. The methodological base is the questionnaire form as a data collection method in Duzce province (Turkey) between March and May 2018. Participation in the study was conducted by convenience sampling method. In the research purpose line, a model is comprised. In turn, a path diagram was performed according to the confirmatory factor analysis with a Structural Equation Model. The obtained results showed the negative relationship between life satisfaction and sub-dimensions of impulse buying (positive emotions, emotion conflict, unplanned behaviour, and mood management). The authors noted only a positive relationship between life satisfaction and rational behaviour in the study. Thus, that is another sub-dimensions of impulse buying. Besides, comparing the mean, there was a significant difference between positive emotions, unplanned behaviour, type and shopping channels. These findings could help future studies aimed at researching the effect of different variables on impulsive behaviours. This study was carried out in a short period due to time and cost constraints. One of the study's limitations is that the study data were obtained only from the participants in Duzce province (Turkey).
\end{abstract}

Keywords: life satisfaction, impulse buying, online shopping, offline shopping, shopping channels.

Introduction. Carpe diem refers to «enjoy the day», «enjoy the time» or, in the most popular sense, «seize the day» in a verse of Horatius, one of the most important Roman poets of the Augustus period and one of the famous names of Latin literature. The exact context of the word is Carpe diem, quam minimum credula postero. It could be literally translated as: gather today, trust tomorrow as little as possible. The most important message in this phrase is to enjoy and emphasize the present's value and the moment, rather than worrying about the future. It encourages people to postpone unnecessary things because every life eventually comes to an end (Bentley, 1995). Time is increasingly seen as a source of competitive advantage in business.

In that way, society constantly switching to a term in which people seek to engage are identical. Successful involvement in a changing society entails sustained communication techniques that depend on understanding their fundamental values and key drivers influenced by society (Johnson, 2011). The point that current society has reached is an environment where everybody does a certain amount of

Cite as: Ata, S., \& Sezer, A. (2021). Evaluating the Effects of Life Satisfaction on Impulse Buying Behavior in Terms of Online Buying. Marketing and Management of Innovations, 1, 38-55. 38 http://doi.org/10.21272/mmi.2021.1-04 
shopping to meet some of their needs. Sometimes, they could buy things they don't need at all, under the influence of different emotions as joy, sadness and anger. In other words, it is the reflection of instant emotions on actions. With the development of technology and the widespread use of communication tools, consumers' shopping preferences have evolved towards online shopping over the Internet. It is observed that a significant portion of the young population is increasingly eager to become online consumers, that they make their first shopping experiences online, and that a large part of the young people give priority to online shopping in their shopping preferences (Chen, 2009). At this point, Carpe Diem comes into play. Consumers have begun to buy not only because they need it, but also to change their daily mood, to spend time forgetting some bad experiences, to have fun or to express themselves. This hedonistic benefit replaces the basic benefit provided by the product, and technological changes have enabled it. When you walk or go somewhere, imagine that you are just a visitor there. Maybe you came from another country as a tourist and you are trying to explore your surroundings thoroughly. Maybe you even come from another planet and you are just noticing everything. Online shopping is exactly that. It is to instantly reach new channels and to capture the dominant thinking mechanism of the consumer with new and different product and service categories.

Arnold and Reynold (2003) explained such purchasing behaviour as follows. Adventure-based shopping, which means experiencing different environments that stimulate excitement, adventure and emotions, social-based shopping emphasizing the social benefits of shopping with friends and family, pleasure-based shopping to create a positive feeling such as feeling better or making someone else feel better shopping is thought-based shopping for the purpose of learning about new trends, fashion and products, role-based shopping for others and that brings out the happiness when the perfect gift is found, and value-based shopping that reflects the pleasure of pursuing bargains, catching discounts, and looking for special sales. In this way, carpe noctem refers similar to «carpe diem» meaning «to catch the night, not to miss the night». It is mostly said to contribute to the motivation of people working from the early hours of the morning to complete a job. It means making good use of the fun of the night after a hard day when the job is completed. In other words, it means leave whatever you lived with, wherever and with whom today (Vasseur, 2011). Apart from the reason why consumers need to purchase products and services, impulse buying (Gerlevik, 2012), which refers to the fact that consumers start to buy to change their bored mood, enjoy their time, have fun or reflect their own personality, and its determinants are physical, social, emotional In this study, both Latin concepts are comprehended as the reference of life satisfaction, which are mental health, psychological wellbeing, having the ability to communicate effectively and effectively, being able to initiate and maintain social relationships, and having social connections (Cruice et al., 2003) emphasis is placed on.

Literature Review. Living in a «happy» life is one of the premise goals of life for many individuals. Problems such as how to reach happiness, what happiness tried to reach is and whether it is affected or not are confronted as an important issue that has not been lost its currency for humanity (Çivitci, 2012). Happiness is one of research subject in the field of psychology, especially positive psychology. Positive psychology advocates an understanding that it is not enough to eliminate the negative situations (such as illnesses and disasters) that one faces in life and that it is also important to protect and develop positive gains and characteristics (love, responsibility, authenticity, morality) (Seligman, 2002). In the literature, the concept of happiness is generally expressed in terms of «subjective wellbeing». Subjective wellbeing involves three interrelated elements: positive affect, negative affect, and life satisfaction. While the positive and negative affect are composed of pleasant and unpleasant feelings, life satisfaction includes cognitive evaluations of the individual's life. Positive affect and perceived high level of life satisfaction indicate that subjective wellbeing is also high (Diener and Suh, 1997). Life satisfaction is the cognitive dimension of subjective wellbeing (Eid and Larsen, 2008) and is considered a happiness indicator (Myers and Diener, 1997). Life Satisfaction by Bearon (1989); is defined as the relationship between the desired situation and the actual situation or actual achievement. Shichman and Cooper (1984) define life satisfaction as having 
a better life, enjoying life and having better quality of life in general. Life satisfaction is the result of comparing individuals with their desire in the life. Neugarten et al. (1961) stated that there are five measures to determine the level of life satisfaction of elderly individuals. In this context, elderly individuals with high level of life satisfaction; the pleasure of activities in everyday life, the existence of goals in life and the values of these goals, to preserve the belief in reaching the objectives for life, being self-confident and protecting the believes that are valuable even in aged time, and it is expected to have an optimistic view towards life.

Impulse buying is a widespread aspect of consumers' behaviour and a focal center for an important marketing activity (Rook, 1987). In the definition of this behavior, though early marketing researches define impulse buying solely as unplanned buying behaviour (Cobb and Hoyer, 1986). The consumer may have limited time, or the consumer may have come to the shop for the first time. Apart from these, consumer remembers that he/she should buy a product that he saw on the raft or in the shop window, and the unplanned purchase takes place. However, in today's marketing literature, researches mostly focus on the consumer's impulsive buying behaviour as the behaviour that occurs with «a sudden unbearable desire that a consumer cannot resist». It shows that in an early time, rather than its psychological aspects, remarkable side of the concept could be thought as being simple and comprehensible (Dhaundiyal and Coughlan, 2009). Psychological side of the concept begun to be studied after 1980's. Rook (1987) defines behaviour as the behaviour appearing in consideration of conflict between emotions which are triggering and this behaviour arises as a result of an abrupt, substantial and insistent spur to buy. Even Cobb and Hoyer (1986) have classified that consumers who intend to buy in a specific product category are planned ones, who intend to buy in a specific product category, however do not specified a certain brand are partially planned persons and who do not intend to buy in a certain product category and brand are impulse buyers. Piron (1993) in his research emphasizes four significant points that clarify the concept widen. Buying behaviour is precisely unplanned, it stands on decision making impulsively, it emerges as a result of exposing to a stimulus and it includes emotional reactions. Buying impulsively, as it seen, are not only depend on product and brand, but are also based on personal and psychological factors. Unplanned buying tendencies of consumers are determined as a factor of personality and therefore unplanned tendency to buy as an individual difference have been conceptualized (Verplanken and Herebadi, 2001).

In addition to obtaining physical satisfaction in the purchase of goods by consumers, gaining emotional satisfaction has led to take into consideration positive effects of impulse buying behavior. As well as basic benefits provided by goods, consumers buy goods on account of emotional benefits. These benefits could be hedonic reasons such as entertainment, feeling oneself special and astonishment, surprise and etc. (Hausmann, 2000).

It is possible to list some factors that affect impulsive buying in the following way: (Virvilaite et.al. 2011). Consumers who show sudden purchasing behaviour when compared to planned purchases show more dominant feelings and emotions such as enthusiasm, fun, happiness, joy and excitement (Weinberg and Gottwald,1982). Beatty and Ferrel (1998) suggest that there is a relationship between consumer buying moods and impulse buying behavior. Youn and Faber (2000) also stated that one's feelings and mood are internal triggers that affect impulse buying. Verplanken and Herabadi (2001) found similar results in their studies. The impulse buying behaviour is related to individuals who want to escape from psychological emotions, such as negative mood and low self-esteem. Yu and Bastin (2010) stated that hedonic reasons and individual factors are related to each other and cause impulse buying behaviour together. Park et al. (2006) studied the relationship between hedonic and fashion aspect and impulse buying behavior. Fashion oriented impulse buying is effected indirectly by hedonic consumption since people who are fashion oriented always looks for fun and enjoyments. Piron (1991) emphasized that consumer could encounter some stimulus such as promotional stimuli and visual stimulus and impulse buying could be induce by these stimulus. It is explicitly seen that marketing activities effectively influence on impulse buying behavior. In recent studies Store, sale atmosphere such as, views, sound and promotion activities and 
visual aspects are significant stimulants which may trigger and bring about emerging of impulse buying behaviour (Graa et al., 2014). Influence of gender on impulse buying behaviour could be predictable. Cobb and Hoyer (1986) stated that women make less impulse buying than men since men do not know where product could be bought and it could be cheaper, nevertheless, women make a shopping list and they are usually familiar with stores and product. However, there are studies in the literature that show ladies have more impulse buying behaviors than men. Alagöz and Ekici (2011) in their study, have determined that women make more impulse buying purchases than men. Age is one of the other significant determinants that affect impulse buying behavior. Wood (1998) stated that when spending money, rather than older people, youngsters are willing to take risk and it shows that when compared other age ranks, impulse buying behaviour is at higher level between ages 18 to 39 . In the literature, it is seen that buying behaviors are divided into two as planned and unplanned purchases. According to the definition of Stern (1962): «Behaviour that is put forward in a way that will take time to search for information to show rational buying behavior» is called planned buying behavior. Unplanned buying behaviour is defined as instantaneous (impulsive) purchasing behaviour without such planning. On the basis of this definition, researchers claim that the most important feature that separates planned and impulse purchase behaviour is the relative speed of purchase.

Today's technological developments have influenced the development of electronic retailing and electronic shopping (Izgi and Şahin, 2013), due to the increasing use of the Internet and the increasing time constraints associated with changing living conditions. The growing popularity of the Internet makes traditional retailing an electronic environment and allows businesses to market their products over the Internet. Thanks to new computer and communication technologies, consumers are able to shop all over the world without leaving their homes. Electronic retailing is a type of retailing where retailers and customers interact with each other through an interactive electronic network. Electronic shopping allows new opportunities in the market to enter new markets easily and at low cost (Enginkaya, 2006).

Another important development that has emerged in recent years is the appearance and rapid spread of the digital platform called social media with the increasing platforms on the Internet. Social sharing platforms have added value in the field of electronic commerce as well as in all areas of the Internet. Findings that these additional platforms which social life and shopping could be shared in the social environment have an impact on electronic commerce, have been influenced by emergence of another subcategory called social commerce (S-Commerce), which provides social meaningful, person-specific products and opportunities by taking data from social networks (Erkan, 2012).

The concept of hedonic consumption and impulsive buying take part in the literature with the realization that the consumer does not show rational behaviour in the decision making process. The unplanned and over-the-run attitudes of individuals towards shopping are causing these concepts to be discussed in academic and professional contexts. The loss of control in shopping is a matter of economic, social and psychological consequences for consumers. In this context, shopping frenzy, over consumption, consumption addiction, oniomania and compulsive buying concepts have started to take place in marketing literature in recent years. (Altunışık et al., 2010).

Impulse buying behaviour is a disturbance that occurs as a result of the impulse of the individual and the inability to control it, resulting in financial difficulties. People with impulsive purchasing inconveniences become obsessed with shopping due to cultural, social and psychological factors such as social status, moderation, imitation, interest. Impulsive buying tendencies could be terminated by different forms of behaviour, short term and long term. These are re-shopping, feeling bad, post-shop regret, guilt, debt, depression, social isolation and low self-esteem (Korur and Kimzan, 2016). It is necessary to clarify why impulse buying behaviour is related to positive and negative emotions. Understanding why consumers are in a pleasant or unpleasant mood after shopping could be based on self-regulation theory. The selfregulating theory is based on the idea that individuals are motivated to manage multiple standards, goals and ideals that could be complemented or competed at any point in time and withdrawn from a feedback 
cycle. According to the theory of self-regulation, there are four categories of self-directedness goals. Individuals try to control their thoughts, feelings, impulses and performances (Baumeister and Heatherton, 1996; Baumeister and Vohs, 2004). It may imply a regulator that is beneficial to alter emotional states or monitoring the mood. According to Tice et al. (2001), individuals with emotional distress (e.g., anger, fear, loneliness) focus more on short-term goals to get rid of sadness, including being in more impulsive behaviours, the individual could be found in behaviours that are impulsive behaviour-oriented, risk-oriented and, impulsive behaviour including busyness.

On the other hand, this theory recommends two diverse basic drives, each accompanying a different self-regulation strategy. The first drive is subjected to the desire to reach out for good things. This motive focuses on activities, growth, hopes, wishes, aspirations. It is an attribute to focus on promotion. A promotion focus prompts a state of willingness to accomplish progress and gains and consequently standardizes the occurrence or nonappearance of rewards and positive consequences. The second motive depends on the need to evade bad things. This motive makes us focus on duties, compulsions, or responsibilities. Thus, it is referred to as a prevention focus (Verplanken and Sato, 2011).

Internet suitability is a factor that could increase impulse buying by product variety and price advantages. In a technological environment, shopping is the first step of a web browsing process where consumers browse for information and make choices on the Internet. Many consumers pay great attention to browsing the web and collecting information while shopping online. There is a long stream of browsing behaviour that allows consumers to remove or reduce risks associated with their shopping duties. Web browsing is divided into two different categories as utility and hedonist. Utilizing screening intentions, it tries to achieve products with goal-oriented behaviour and risk-reducing strategies.

On the other hand, hedonic scanning is more interested in the fun and enjoyable aspects of shopping, whether it is a purchase or not. The main concern of web browsers is to buy products in a timely and efficient manner, with minimal effort and ease. But the fun and engaging opportunities of web browsing play an important role in enhancing the joyful shopping experience. Whether making a purchase or not doing a search in the technological environment, consumers are looking for information on a wide range of products and taking pleasure (Park et al., 2012).

Intensive and active using the Internet in daily life, development in devices giving access to the Internet and connection, affects consumers' buying behaviour to a great extent by putting into practice smart mobile phones connected to the Internet. With smart mobile devices, the concept of mobile retailing has emerged to express purchasing made via the Internet. Almost every sector, especially the communication and retail sector, has been affected by the emergence and widespread use of mobile phones and mobile devices. Mobile tools offer different opportunities by moving beyond e-shopping mediated by trade and shopping computers (Tatıdil et al., 2012). Internet and the rapid growth of multichannel retailing, consumers are now exposed to marketing stimuli that encourage continuous uncontrolled purchases. The Internet plays a role as an alternative uncontrolled purchasing channel, enabling consumers to shop 7/24 a week in the comfort of their homes in their spare time (Dawson and Kim, 2009).

Methodology and research methods. The purpose of this research is to reveal to what extent the life satisfaction of individuals has an effect on impulsive buying behaviours based on the self-regulation theory. Moreover, it aims to research whether participants' impulsive buying behaviour and life satisfaction differ in online/offline shopping behaviour.

The population of the research consists of consumers who shop offline or online. The study sample consists of 212 consumers who reside in Duzce. They were selected by a random method. In the research, the survey technique, one of the quantitative research methods, was chosen as the data collection method. The questionnaire form was applied in Duzce province and via e-mail between March and May, 2018. The convenience sampling method was used in the selection of the people to participate in the study. It stands to mention that the study limited by doing research only in Duzce. The analysis only represents the sample. Thus, the obtained results couldn't be generalized. 
Table 1. Distribution regarding the demographic characteristics of the participants

\begin{tabular}{lcc}
\hline Gender & Frequency & $\%$ \\
\hline Female & 136 & 64,2 \\
Male & 76 & 35,8 \\
Tota & 212 & 100 \\
\hline Do you shop as online? & Frequency & $\%$ \\
\hline Yes & 161 & 75,5 \\
No & 51 & 24,5 \\
\hline Online Shopping Channels & Frequency & $\%$ \\
\hline Social Media & 22 & 10,4 \\
Shopping Websites & 139 & 65,5 \\
None & 51 & 24,1 \\
Total & 212 & 100 \\
\hline
\end{tabular}

Sources: developed by the authors.

As seen in Table 1, approximately $65 \%$ of the participants are women, and $35 \%$ are men. Considering whether the participants do online shopping or not, it is seen that about $75 \%$ of them shop online, while $25 \%$ do not shop online. Analysis of the channel selection used for online shopping shows that most participants use shopping sites.

Table 2. Crosstab for gender and online/offline shopping

\begin{tabular}{lcccc}
\hline \multicolumn{1}{c}{ Crosstab } & \multicolumn{2}{c}{ Online Shopping Channels } & \multirow{2}{*}{ Offline Shopping } & Total \\
\hline Gender & Social Media & Shopping Websites & & 138 \\
Female & 18 & 86 & 32 & 76 \\
Male & 4 & 53 & 19 & 212 \\
Total & 22 & 139 & 51 & 212 \\
\hline
\end{tabular}

Sources: developed by the authors.

Table 2 consists of gender distribution and type of shopping (as channels), and online/offline status. Females who overwhelmingly prefer online shopping $(76 \%)$ use mostly shopping websites $(63 \%)$, subsequently social media (13\%) and offline shopping (24\%). Accounts for males are subsequently shopping websites (69\%), social media (5\%) and offline shopping (25\%). The research conducted is a quantitative study in terms of the perspective on which it based. Although it is an empirical study according to the data collection technique, it evaluates the primary data according to the characteristics of the research's data. These data are in the form of instant data. Due to the nature of the research and time constraints, a questionnaire was used as a data collection technique. In general, the questionnaire is defined as «the method of obtaining data by responding to a set of questions formed in a predetermined order and structure» (Altunışık et al., 2007). Impulse buying scale and life satisfaction scale were used in this study, which was conducted to determine the effect of individuals' impulse buying behaviours on their life satisfaction. Exploratory and confirmatory factor analyzes were applied to the scales, and analysis results were also included. Exploratory factor analysis is a statistical analysis method that aims to determine the factors that are less than the relevant variables. There is no correlation between them by using the relationships between variables in a data set (Özdamar, 2013). On the other hand, Confirmatory factor analysis is a process of creating latent variables based on observed variables through a previously developed model. It is a method generally used to develop scales, to conduct validity analyses or verify a predetermined structure (Aytaç and Öngen, 2012). In the questionnaire form, two scales consist of thirtythree items to measure impulse buying behaviour and five items - life satisfaction and questions about demographic characteristics. The relevant scales are intended to determine the respondents' level of 
participation (1: strongly disagree ... 5: strongly agree) to the scale's expressions. To measure impulse buying behaviour, 33 questions and 6 sub-dimensions in the form designed by Youn and Faber (2000) and adapted for Turkish consumers by Dursun and Yener (2014) were used. Another scale accepted and frequently used in the literature is Weun et al. (1998). However, comparing the scale of Weun et al. (1998) and Youn (2000) according to the reliability coefficient showed that Youn's (2000) scale was more reliable for Turkish consumers (Dursun and Yener, 2014). It was evaluated with a 5-point Likert scale in two scales in the questionnaire.

To reveal items and dimensions, exploratory factor analysis was conducted. Kaiser-Meyer-Olkin (KMO) sampling adequacy coefficient was found to be 0.885 , and Bartlett's test of sphericity was significant at the 0.00 level. Table 3 demonstrates the exploratory factor analysis and reliability analysis results for impulse buying behaviour.

Table 3. Exploratory factor analysis and reliability analysis findings

\begin{tabular}{|c|c|c|c|}
\hline \multicolumn{4}{|c|}{ Unplanned Purchasing } \\
\hline Items & Factor Loadings & Items & Factor Loadings \\
\hline - UB6 & 0.671 & - UB32 & 0.568 \\
\hline . UB7 & 0.664 & - UB8 & 0.539 \\
\hline - UB 4 & 0.621 & - UB3 & 0.530 \\
\hline - UB31 & 0.582 & - UB33 & 0.437 \\
\hline Explained Variance & 0.05 & Reliability Score & 0.819 \\
\hline \multicolumn{4}{|l|}{ Emotion Conflict } \\
\hline - EC11 & 0.807 & - EC9 & 0.722 \\
\hline - EC10 & 0.802 & - EC12 & 0.719 \\
\hline - EC13 & 0.748 & & \\
\hline Explained Variance & 0.06 & Reliability Score & 0.836 \\
\hline \multicolumn{4}{|l|}{ Rational Behavior } \\
\hline - RB27 & 0.840 & - RB25 & 0.682 \\
\hline - RB28 & 0.828 & - RB24 & 0.502 \\
\hline - RB26 & 0.825 & & \\
\hline Explained Variance & 0.10 & Reliability Score & 0.831 \\
\hline \multicolumn{4}{|l|}{ Positive Emotions } \\
\hline - PE17 & 0.794 & - PE 15 & 0.709 \\
\hline - PE 14 & 0.784 & - PE 16 & 0.652 \\
\hline - PE 18 & 0.766 & & \\
\hline Explained Variance & 0.12 & Reliability Score & 0.897 \\
\hline \multicolumn{4}{|l|}{ Mood Management } \\
\hline - MM22 & 0.798 & - MM20 & 0.727 \\
\hline - MM21 & 0.780 & - MM19 & 0.667 \\
\hline - MM23 & 0.769 & & \\
\hline Explained Variance & 0.30 & Reliability Score & 0.907 \\
\hline $\begin{array}{l}\text { Extraction Method: } \\
.63 ; \mathrm{KMO} \text { Sampling }\end{array}$ & $\begin{array}{l}\text { nent Analysis; Ro } \\
; p=0,000<0.001\end{array}$ & thod: Varimax;To & Explained Variance \\
\hline
\end{tabular}

Sources: developed by the authors. 
Result of the factor analysis made for the impulse buying behaviour variable «Sometimes I suddenly feel the desire to buy and buy something» on the grounds that they have low factor loadings and have cross-factor loading. Expressions such as «When I feel a desire to buy something, I buy it as quickly as possible so as not to worry about not having bought it. «When I see a product that attracts me in a store, I feel helpless», "I also buy some clothing items that I do not intend to buy when I go shopping», «When I go shopping, I buy things I didn't plan to buy before» were removed. Then discovery factor analysis was repeated.

As a result of the analysis, expressions related to the dimensions of «not being able to resist purchasing» and «not thinking about the future - acting unplanned» were gathered under one dimension and named as «unplanned purchasing behaviour». As a result, a five-dimensional structure with a total variance of 63 was obtained.

Özdamar (2013) states the criterion values for the reliability coefficient as follows: 1) if the scale is not reliable in the range $0.00<\alpha<0.40$, it is low reliable in the range of $0.41<\alpha<0.60$, average reliable in the range of $0.61<\alpha<0.80 ; 2$ ) if it is in the range of $0.81<\alpha<1.00$ it is highly reliable. The reliability analysis results for the sub-dimensions of impulse buying behaviour are shown in the table from top to bottom, respectively, 819; 836; 831; 897; It was determined as 907 . The given value ranges indicated that the reliability analysis results for all dimensions are highly reliable.

Table 4. Confirmatory factor analysis findings

\begin{tabular}{lccc}
\hline Fit Indices & Acceptable Values & Perfect Values & Actual Values \\
\hline$X^{2} /$ df & $2 \leq \mathrm{X}^{2} / \mathrm{df} \leq 5$ & $0 \leq \mathrm{X}^{2} / \mathrm{df} \leq 2$ & 1.686 \\
GFI & $0.80 \leq \mathrm{GFI} \leq 0.95$ & $0.95 \leq \mathrm{GFI} \leq 1.00$ & 0.859 \\
CFI & $0.80 \leq \mathrm{CFI} \leq 0.95$ & $0.95 \leq \mathrm{CFI} \leq 1.00$ & 0.932 \\
TLI & $0.80 \leq \mathrm{TLI} \leq 0.95$ & $0.95 \leq \mathrm{TLI} \leq 1.00$ & 0.923 \\
RMSEA & $0.05 \leq \mathrm{RMSEA} \leq 0.10$ & $0.00 \leq \mathrm{RMSEA} \leq 0.05$ & 0.057 \\
\hline
\end{tabular}

Sources: developed by the authors based on (Schermelleh-Engel et al., 2003; Hooper et al., 2008; Simon et al., 2010; Marsh et al., 2012; Kline, 2011).

As a result of the confirmatory factor analysis, the error terms of the UPB8 coded expression (the Unplanned Behaviour dimension) and the PE15 coded expression (the Positive Emotions dimension) were excluded from the measurement model because they were correlated with many expressions (Byrne, 2010). On the other hand, the standardized factor load of the RB24 coded expression belonging to the Rational Behaviour dimension was removed from the measurement model because it was lower than 40 (Byrne, 2010). Herewith, the current model was used in other analyses to be conducted within the study's scope. The confirmatory factor analysis result of the impulse buying variable showed that the value of $\mathrm{X} 2 / \mathrm{df}$ from the goodness of fit values was in the perfect value range. In turn, the other fit values were in the acceptable value range. Table 3 shows the actual values resulting from the analysis and the acceptable values and perfect values. Figure 1 demonstrates the model diagram.

Individuals' general life satisfaction levels were measured using the Life Satisfaction Scale developed by Diener et al. (1985) and adapted to Turkish validity. Reliability analysis was made by Köker (1991). Under reflecting how the individual evaluates his/her life in general, the scale aimed at measuring the perceived general life satisfaction. Increasing the scores obtained from the scale consisting of five items indicate that the perceived general life satisfaction level increased. An example of the scale items is «I have achieved the important things I wanted in life so far». In the relevant study conducted by Köker, it was observed that the reliability coefficient of the scale was $a=0.852$. Considering the value ranges given by Özdamar (2013), it is highly reliable. 


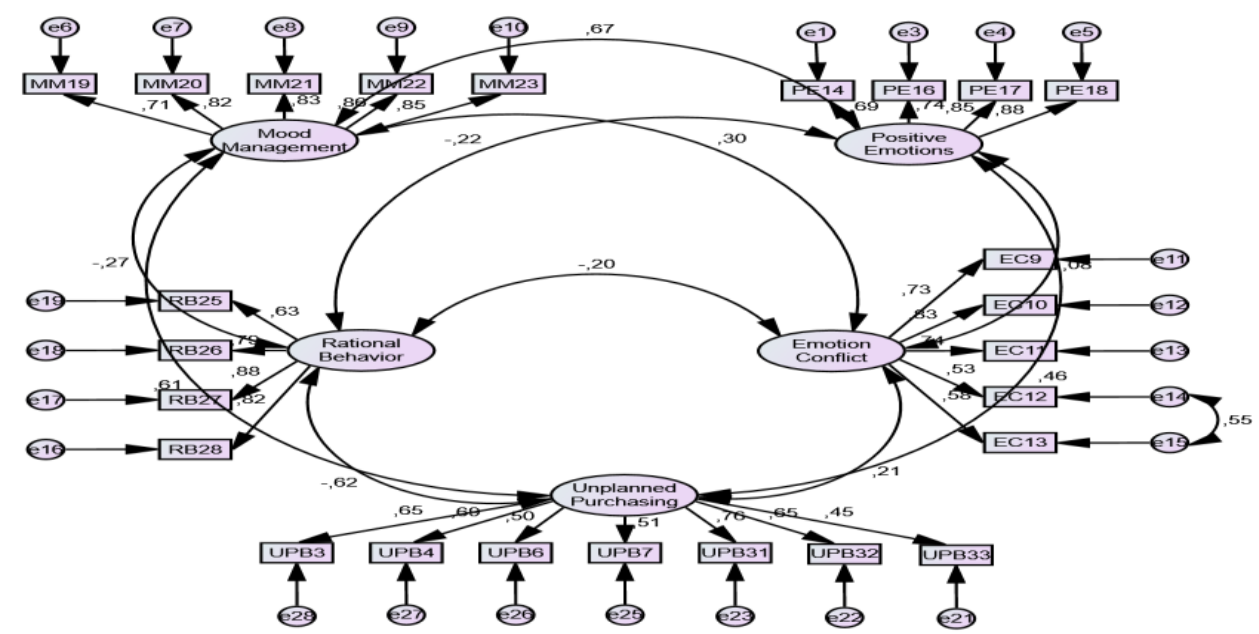

Figure 1. Impulse buying confirmatory factor analysis diagram

Sources: developed by the authors.

Table 5 shows that factor loads and explained variance are adequate to process the study and findings. To confirm in line with the structure, it is finalized that confirmatory factor analysis is conducted.

Table 5. Exploratory factor analysis and reliability analysis findings

\begin{tabular}{cccc}
\hline Variables & Factor Loadings & Variables & Factor Loadings \\
\hline - LS5 & 0.848 & - LS2 & 0.752 \\
- LS1 & 0.812 & - LS3 & 0.746 \\
- LS4 & 0.801 & Extraction Method: Principal Component Analysis; \\
Reliability Score & 0.852 & Rotation Method: Varimax; Total Explained Variance: \\
Explained Variance & 0.63 & $.63 ;$ KMO Sampling Adequacy: $.85 ; p=0,000<0.001 ;$ \\
\hline
\end{tabular}

Sources: developed by the authors.

Table 6. Confirmatory Factor Analysis Findings

\begin{tabular}{lccc}
\hline Fit Indices & Acceptable Values & Perfect Values & Actual Values \\
\hline X $^{2} / \mathrm{df}$ & $2 \leq \mathrm{X}^{2} / \mathrm{df} \leq 5$ & $0 \leq \mathrm{X}^{2} / \mathrm{df} \leq 2$ & 1.706 \\
GFI & $0.80 \leq \mathrm{GFI} \leq 0.95$ & $0.95 \leq \mathrm{GFI} \leq 1.00$ & 0.984 \\
$\mathrm{CFI}$ & $0.80 \leq \mathrm{CFI} \leq 0.95$ & $0.95 \leq \mathrm{CFI} \leq 1.00$ & 0.992 \\
TLI & $0.80 \leq \mathrm{TLI} \leq 0.95$ & $0.95 \leq \mathrm{TLI} \leq 1.00$ & 0.983 \\
RMSEA & $0.05 \leq \mathrm{RMSEA} \leq 0.10$ & $0.00 \leq \mathrm{RMSEA} \leq 0.05$ & 0.058 \\
\hline
\end{tabular}

Sources: developed by the authors on the basis of (Schermelleh-Engel et al., 2003; Hooper et al., 2008; Simon et al., 2010; Marsh et al., 2012; Kline, 2011).

As a result of the confirmatory factor analysis for the life satisfaction variable, the goodness of fit values $\mathrm{X} 2 / \mathrm{df}, \mathrm{GFI}, \mathrm{CFI}$ and TLI were in the perfect value range, while the other fit values RMSEA were in the acceptable value range. Table 6 shows the results for the actual values resulting from the analysis and the acceptable values and perfect values. Figure 2 demonstrates the model diagram. 


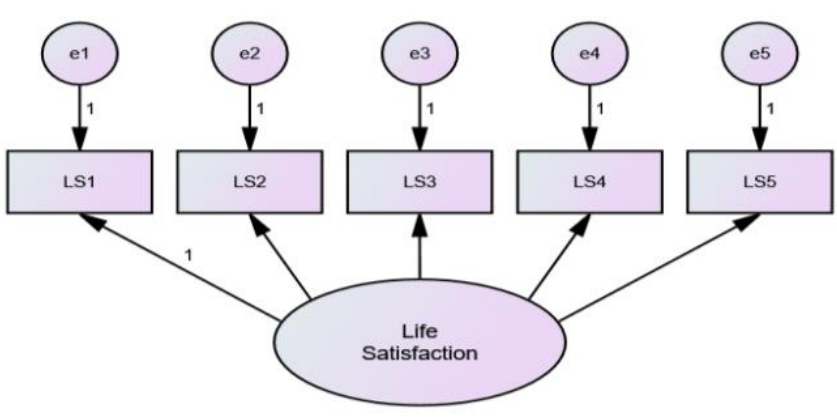

Figure 2. Life satisfaction confirmatory factor analysis diagram

Sources: developed by the authors.

This study refers prediction model, which is one of the relational research methods. Simple regression and multiple regression analysis methods could be used and correlation calculated in predictive models (Metin, 2015). Regression analysis refers to the process of explaining the relationship between two or more variables (as dependent variables) and the others (as independent variables) and the relationship between them with a mathematical equation (Gamgam and Ünver, 1986; Howell, 1987). In this direction, Figure 3 shows the model developed to determine the effect of individuals' life satisfaction on impulse buying behaviour.

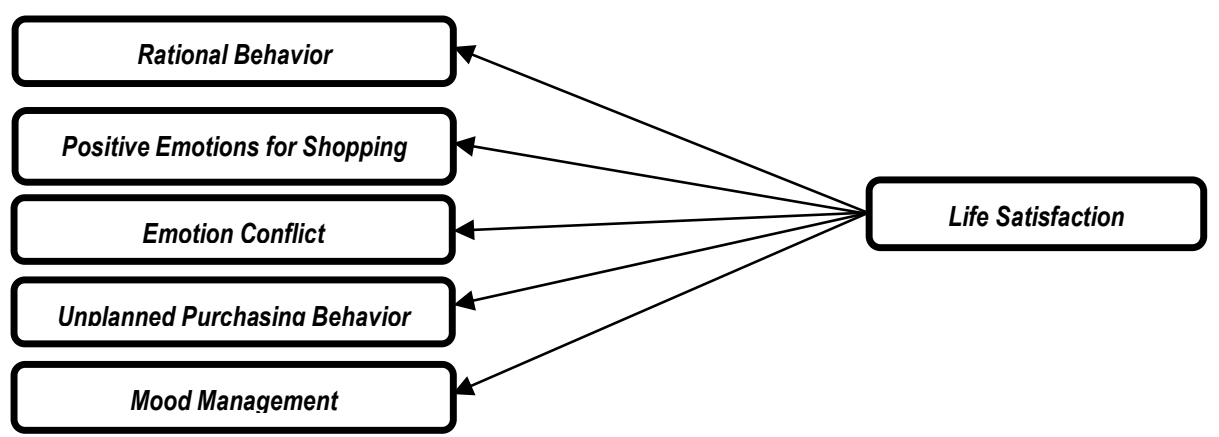

Sources: developed by the authors.

Figure 3. Research model

Under the study (Silvera et al., 2008) containing 277 participants who are students and Englishspeaking in Canadian University, the subjective wellbeing, as a widen structure that shows individual's positive and negative responses to their specific aspect of satisfaction, relates to buying impulse including a lack of planning in the purchasing process. However in the same study, excitement with positive feelings in shopping is effected by the interpersonal influence of wellbeing. The consumer decision process of purchasing could be affected by how they satisfy with life.

Aslan and Şener (2019) found that 65-aged and over consumers' life satisfaction may change according to age. Thus, that age is effective in purchasing decisions. The authors concluded that the relationship between insecurity (the sub-factor of money attitude) and life satisfaction mediated the purchase decision. It was evident that dissatisfaction with life could push the individual to momentary dysfunctional behaviours and may later remorse. Bozdağ Türker (2019) examined variables related to 
compulsive online buying behaviour. The authors found a negative relationship between life satisfaction variable and loneliness, impulsivity, and depression-anxiety-stress, which express the person's mood.

Emotional conflicts reflect sadness, regret, and tension etc., after purchasing. Miao (2011), having studied 278 participants in Pennsylvania in 3 days, found that affective ambivalences trigger impulsive behaviour, and affective ambivalence reveals itself in two delicately but qualitatively changed affective states: "guilty pleasure» and «pleasurable guilt».

This study emphasizes a clear negative relationship between satisfied people and impulsive buying decision related to confliction in emotions. Korur and Kimzan (2016) revealed that compulsive purchasing behaviour had a positive and significant relationship with credit card abuse and post-shopping regret. While shopping in this way, the consumers feel that they are not spending money and only for show or satisfaction. As a result, they enter a period where they may have difficulty paying their debts. Thus, emotional conflicts could occur (Smith et al.,2015). In light of all this information, the following hypotheses have been developed:

$\mathrm{H} 1$ : The life satisfaction of individuals has a statistically significant effect on impulse buying behaviour.

H1a: Individuals' life satisfaction has a statistically significant negative effect on positive emotions for shopping.

H1b: Individuals' life satisfaction has a statistically significant negative effect on emotion conflict.

H1c: Individuals' life satisfaction has a statistically significant negative effect on unplanned behaviour.

H1d: Individuals' life satisfaction has a statistically significant positive effect on rational behaviour.

H1e: Individuals' life satisfaction has a statistically significant negative effect on mood management.

Results. In this part, to determine some differences regarding participants' descriptive features, Ttests are used to determine these differences in terms of means of all dimensions of variables.

Table 7. Comparing means in terms of gender

\begin{tabular}{|c|c|c|c|c|c|c|}
\hline Dimension & Type of Shopping & $\mathbf{N}$ & Mean & S.D & $T$ & $p$ \\
\hline \multirow{2}{*}{ Positive Emotions } & Male & 76 & 2,55 & 0,98 & 0,765 & 0,446 \\
\hline & Female & 136 & 2,66 & 0,94 & & \\
\hline \multirow{2}{*}{ Emotion Conflict } & Male & 76 & 2,63 & 0,93 & 3,41 & $0,001^{* *}$ \\
\hline & Female & 136 & 3,06 & 0,85 & & \\
\hline \multirow[b]{2}{*}{ Unplanned Behavior } & Male & 76 & 2,13 & 0,79 & 0,833 & 0,406 \\
\hline & Female & 136 & 2,22 & 0,71 & & \\
\hline \multirow{2}{*}{ Rational Behavior } & Male & 76 & 3,87 & 0,92 & 0,371 & 0,712 \\
\hline & Female & 136 & 3,49 & 0,94 & & \\
\hline \multirow{2}{*}{ Mood Management } & Male & 76 & 2,31 & 0,95 & 5,62 & $0,000^{* *}$ \\
\hline & Female & 136 & 3,10 & 1,02 & & \\
\hline Life Satisfaction & $\begin{array}{c}\text { Male } \\
\text { Female }\end{array}$ & $\begin{array}{c}76 \\
136\end{array}$ & $\begin{array}{l}3,29 \\
3,30\end{array}$ & $\begin{array}{l}0,80 \\
0,77\end{array}$ & 0,101 & 0,920 \\
\hline \multicolumn{7}{|c|}{ or level * significant at $\%$} \\
\hline
\end{tabular}

Sources: developed by the authors.

As a result of independent sample T-test, the difference between emotion conflict (Xmale=2,63; $X$ female=3,06), $(t=3,41 ; p<0,01)$, mood management (Xmale=2,31; Xfemale $=3,10),(t=5,62 ; p<0,01)$ and group means were found to be statistically significant.

Another independent sample T-test was conducted to determine whether the participants' impulse buying and life satisfaction behaviours differ significantly or not according to their online or offline shopping status. 
Table 8. Comparing means in terms of the shopping type

\begin{tabular}{|c|c|c|c|c|c|c|}
\hline Dimension & Type of Shopping & $\mathbf{N}$ & Mean & S.D & $T$ & $p$ \\
\hline \multirow{2}{*}{ Positive Emotions } & Online & 158 & 2,73 & 0,98 & 2,86 & $0,001^{* *}$ \\
\hline & Offline & 54 & 2,31 & 0,79 & & \\
\hline \multirow{2}{*}{ Emotion Conflict } & Online & 158 & 2,94 & 0,93 & 1,04 & 0,334 \\
\hline & Offline & 54 & 2,81 & 0,80 & & \\
\hline \multirow{2}{*}{ Unplanned Behavior } & Online & 158 & 2,25 & 0,74 & 2,03 & $0,045^{\star}$ \\
\hline & Offline & 54 & 2,01 & 0,73 & & \\
\hline \multirow{2}{*}{ Rational Behavior } & Online & 158 & 3,64 & 0,96 & 0,371 & 0,712 \\
\hline & Offline & 54 & 3,59 & 0,92 & & \\
\hline \multirow{2}{*}{ Mood Management } & Online & 158 & 2,88 & 1,08 & 1,51 & 0,132 \\
\hline & Offline & 54 & 2,64 & 1,00 & & \\
\hline \multirow{2}{*}{ Life Satisfaction } & Online & 158 & 3,34 & 0,75 & 1,18 & 0,239 \\
\hline & Offline & 54 & 3,19 & 0,86 & & \\
\hline \multicolumn{7}{|c|}{ ** significant at $\%, 1$ error level * significant at $\%, 5$ error level } \\
\hline
\end{tabular}

Sources: developed by the authors.

As a result of this test, the difference between positive emotions (Xonline=2,73; $X$ offline=2,31), $(\mathrm{t}=2,86$; $p<0,01)$ and unplanned behaviour (Xonline=2,25; Xoffline=2,01), $(t=2,03 ; p<0,05)$ and group means were found to be statistically significant.

Table 9. Comparing means in terms of shopping channels

\begin{tabular}{clcccccc}
\hline \multirow{2}{*}{ Dimension } & $\begin{array}{c}\text { Shopping } \\
\text { Channels }\end{array}$ & $\mathbf{N}$ & $\mathbf{X}$ & $\mathbf{S . D}$ & $\mathbf{F}$ & $\mathbf{p}$ & Sig. Dif. \\
& Social Media & 22 & 2,63 & 1,08 & & 0,944 & $1>2$ \\
Positive Emotions & Shopping site & 139 & 2,76 & 0,987 & 5,303 & 0,375 & $1>3$ \\
& Offline & 51 & 2,25 & 0,714 & & $0,001^{* *}$ & $2>3^{* *}$ \\
& Social Media & 22 & 3,16 & 0,882 & & 0,559 & $1>2$ \\
Emotion Conflict & Shopping site & 139 & 2,91 & 0,934 & 1,275 & 0,281 & $1>3$ \\
& Offline & 51 & 2,79 & 0,822 & & 0,768 & $2>3$ \\
\multirow{2}{*}{ Unplanned } & Social Media & 22 & 2,50 & 0,817 & & 0,398 & $1>2$ \\
Behavior & Shopping site & 139 & 2,22 & 0,741 & 4,531 & $0,032^{*}$ & $1>3^{*}$ \\
& Offline & 51 & 1,96 & 0,669 & & 0,650 & $2>3$ \\
Rational Behavior & Social Media & 22 & 3,39 & 0,996 & & 0,557 & $1>2$ \\
& Shopping site & 139 & 3,67 & 0,970 & 0,795 & 0,732 & $1>3$ \\
& Offline & 51 & 3,62 & 0,873 & & 0,986 & $2>3$ \\
Mood Management & Social Media & 22 & 2,98 & 1,28 & & 0,988 & $1>2$ \\
& Shopping site & 139 & 2,89 & 1,06 & 2,115 & 0,445 & $1>3$ \\
& Offline & 51 & 2,56 & 0,965 & & 0,120 & $2>3$ \\
& Social Media & 22 & 3,50 & 0,557 & & 0,412 & $1>2$ \\
\hline \multirow{2}{*}{ Life Satisfaction } & Shopping site & 139 & 3,31 & 0,774 & 1,331 & 0,183 & $1>3$ \\
& Offline & 51 & 3,18 & 0,875 & & 0,743 & $2>3$ \\
\hline
\end{tabular}

Sources: developed by the authors.

There is a significant difference between shopping sites and offline shopping according to positive emotions $(F=5.303 ; p=0,001<0,01)$. Another significant difference found is between social media and offline according to unplanned behaviour ( $F=4,531 ; p=0,032<0,05)$.

At this stage, the dimensions obtained from exploratory and confirmatory factor analyses and the research hypotheses developed within the scope of the research were tested with the structural equation model. Table 10 shows the analysis results. Figure 4 demonstrates the effect model diagram. 
Table 10. The goodness of fit of the model

\begin{tabular}{lccc}
\hline Fit Indices & Acceptable Values & Perfect Values & Actual Values \\
\hline $\mathrm{X}^{2} / \mathrm{df}$ & $2 \leq \mathrm{X}^{2} / \mathrm{df} \leq 5$ & $0 \leq \mathrm{X}^{2} / \mathrm{df} \leq 2$ & 2.017 \\
GFI & $0.80 \leq \mathrm{GFI} \leq 0.95$ & $0.95 \leq \mathrm{GFI} \leq 1.00$ & 0.802 \\
$\mathrm{CFI}$ & $0.80 \leq \mathrm{CFI} \leq 0.95$ & $0.95 \leq \mathrm{CFI} \leq 1.00$ & 0.871 \\
TLI & $0.80 \leq \mathrm{TLI} \leq 0.95$ & $0.95 \leq \mathrm{TLI} \leq 1.00$ & 0.858 \\
RMSEA & $0.05 \leq \mathrm{RMSEA} \leq 0.10$ & $0.00 \leq \mathrm{RMSEA} \leq 0.05$ & 0.069 \\
\hline
\end{tabular}

Sources: developed by the authors on the basis of (Schermelleh-Engel et al., 2003; Hooper et al., 2008; Simon et al., 2010; Marsh et al., 2012; Kline, 2011).

Figure 3 gives the path analysis of the proposed structural equation model. The effect model analysis results showed that all goodness of fit values are within the acceptable values range. Table 11 shows parameter estimates of the structural model that provides the goodness of fit values.

Table 11. Standardized regression coefficients and parameter estimates for the model

\begin{tabular}{cccccc}
\hline $\begin{array}{c}\text { Exogenous } \\
\text { Variable }\end{array}$ & $\begin{array}{c}\text { Endogenous } \\
\text { Variable }\end{array}$ & $\begin{array}{c}\text { Std. Reg. } \\
\text { Coefficient }\end{array}$ & Std. Error & P-Value \\
\hline Life Satisfaction $\longrightarrow$ Positive Emotions & -0.242 & 0.088 & $\mathbf{0 . 0 0 3}^{* *}$ \\
Life Satisfaction $\longrightarrow$ Emotion Conflict & -0.218 & 0.093 & $\mathbf{0 . 0 0 8}^{* *}$ \\
Life Satisfaction $\longrightarrow$ Unplanned Behavior & -0.250 & 0.065 & $\mathbf{0 . 0 0 5}^{* *}$ \\
Life Satisfaction $\longrightarrow$ Rational Behavior & 0.184 & 0.100 & $\mathbf{0 . 0 1 9}^{*}$ \\
Life Satisfaction $\longrightarrow$ Mood Management & -0.157 & 0.094 & $\mathbf{0 . 0 4 2}^{*}$ \\
\hline${ }^{* *}$ significant at \% ,1 error level ${ }^{*}$ significant at \% ,5 error level & &
\end{tabular}

Sources: developed by the authors.

Table 11 shows that life satisfaction has significant $(p<0.001)$ and negative effects on unplanned behaviour, positive emotions, emotion conflict dimensions ( $-0.250 ;-0.242 ;-218$ respectively), which are the sub-dimensions of impulse buying. Moreover, life satisfaction has a significant $(p<0.05)$ and a negative effect on mood management $(-0.157)$. Besides, life satisfaction has a significant $(p<0.05)$ positive impact on the rational behaviour dimension. In other words, $\mathrm{H} 1 \mathrm{a}, \mathrm{H} 1 \mathrm{~b}, \mathrm{H} 1 \mathrm{c}, \mathrm{H} 1 \mathrm{~d}$, and $\mathrm{H} 1 \mathrm{e}$ are accepted.

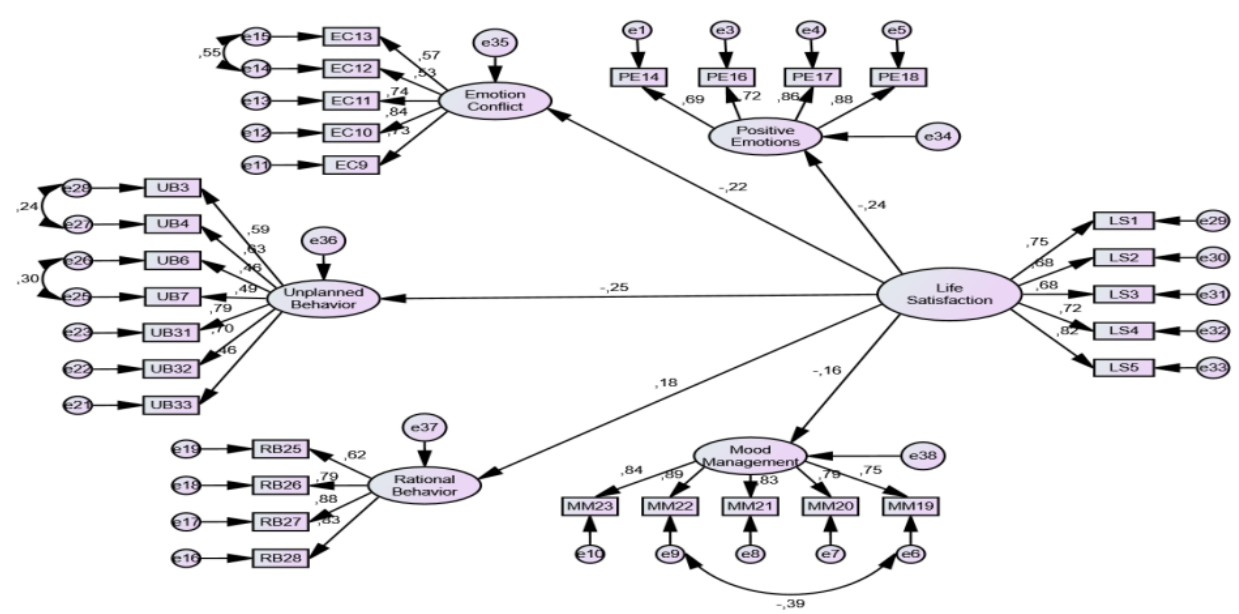

Figure 4. The path analysis of the model

Sources: developed by the authors. 
Conclusions. It is quite natural nowadays that people tend to buy things to make a difference in their lives and increase their happiness because they get bored, tired after an extremely busy and stressful day, and want to reward themselves. Thus, consumption has become a means of satisfaction for people who want to meet their psychological needs and enjoy. That is why it is referred to carpe diem and carpe noctem to identify life satisfaction effects on impulse buying behaviour. Consumers could get away from their usual problems by shopping from the perspective of these concepts.

This study aimed to determine whether impulse buying behavior, which could be a source of inspiration for happiness and satisfaction in people's lives, really takes shape based on life satisfaction. This aim was explained in a theoretical framework with the self-regulation theory (Baumeister and Heatherton, 1996; Baumeister and Vohs, 2004; Tice et al., 2001). It emphasizes that individuals avoid situations and activities that may make them feel worse, such as receiving negative feedback about themselves and dealing with a boring job when they are in a positive mood. Moreover, this study tried to be clarified such questions «do people behave more rationally if they suddenly feel the desire to buy at the point where they are really satisfied with their lives, do they remain in the conflict in emotional terms, or when they encounter tension and stress, do they attempt to buy without thinking or planning». The other point is whether shopping is online or offline. There is an attempt to explain whether all these behaviors are shaped by online or instore shopping and if it is from the Internet, according to which online channels. Exploratory factor analysis was carried out to determine the dimension of the impulse buying variables. According to the result, a structure with 5 factors (Positive Emotions, Emotion Conflict, Unplanned Behavior, Rational Behavior, Mood Management) was obtained. The scale's original is a 6 -factor structure, but the inability to resist purchasing and overlooking to future is combined under the unplanned behaviour dimension in this study. Logically, the inability to resist purchasing and disregarding the future could be considered equivalent to purchasing behaviors made by ignoring many factors without planning. Afterwards, confirmatory factor analysis was performed to test the structural validity of the dimensions obtained. The structural equation model was established with the variables under provided structural validity. Thus, the model was analyzed. According to the analysis results, the statistically significant negative effect of individuals' life satisfaction on unplanned purchasing behaviour, positive emotions for shopping, emotion conflict and mood management dimensions. The obtained results showed the statistically significant negative effect on the rational behaviour dimension. In other words, while life satisfaction of individuals has a positive effect on the rational behaviour dimension of impulse buying behaviour, it has a negative effect on all other dimensions that could be expressed as irrational behaviour. In short, happy individuals with a high level of life satisfaction have more rational purchasing behaviour. In the section that the researcher divides the concept as Happiness-as-connection-to-objective-preexisting-good, objectivity is to reach more extreme points for the individual and is directly proportional to the objectivity and logic of the individual. It could be in the same direction for buying decision process. Virvilaite et al. (2011) stated that impulse buying is affected by emotions and hedonic reasons. Besides, Beatty and Ferrel (1998) found a relationship between consumers' positive emotions and their impulse buying desire. Youn and Faber (2000) also stated that a person's emotions and moods affect impulse buying. Willis (1991) emphasizes that «No product fully responds to the consumer's desires and expectations and puts the consumer in the expectation of the following goods». Furthermore, human beings relate happiness to consumption, while hedonism's seductive effect forms the basis of consumption addiction. Generally, the happiness of the behaviour leading to addiction takes a short time, and then the person feels great regret or guilt (Solomon, 2003). Therefore, consuming as a search for happiness results in unhappiness. Considering that making impulse buying behaviour is a tool to get rid of unhappiness, it could be thought that happy individuals would not tend to buy this tool instantly. Therefore, individuals who tend to exhibit impulse buying behaviour would be affected by their level of life satisfaction, that is, their happiness state, and would act in purchasing. The study results were reached and supported in line with the mentioned studies. Besides, according to the T-test and Anova test conducted to analyze the differences, emotion conflict and mood management, 
which are among the impulsive buying sub-dimensions, differ according to the gender of the individuals. At this point, women tend to prefer more impulse buying behaviours to get rid of emotional conflict and negative mood compared to men. Coley and Burgess (2003) found that women consumers make unplanned purchases. Men have a shopping list with them while going to their shopping and buying nothing more. When women see the product in the market, they remember the need for that product. Sometimes, they are attracted to the discount and promotion on the product and make purchases even if they are not needed. In another difference analysis, the dimensions of variables used in the study were examined according to the type of purchase. It was determined that there was a difference in the dimensions of impulsive buying, positive emotions for shopping, and unplanned behavior, according to online and offline purchasing types. It was concluded that individuals with online purchasing behaviour have more unplanned instant purchasing behaviour than offline purchasing behaviour. They shop because they have positive feelings about shopping. Erdem et al. (2015) noted that consumers' impulsive motivations affect impulsive online purchasing, whether in cognitive or emotional dimensions. In this context, all the impulsive motivations (social, role/idea, adventure, pleasure-based shopping motivations, stress, emotions, etc.) affect consumers' online impulsive buying tendencies. Finally, in another analysis of differences, it was concluded that there was a difference in the means of the dimensions of positive emotions for shopping and unplanned behaviour according to the purchasing channels of individuals. According to this result, it is seen that individuals who use social media as a purchasing channel have more unplanned purchasing behaviour compared to individuals using offline channels. Besides, individuals who buy from shopping sites have more positive feelings about shopping than those who buy from offline channels.

If looking at the analysis results in terms of meaning, it is seen that in today's world, where materialism is increasing, materialism causes individuals to exhibit certain behaviours such as acquiring assets, losing wealth and buying unconsciously. It is stated that the concept of impulse buying is an unconscious consumption behaviour that results in negative feelings and thoughts such as unhappiness, dissatisfaction and regret. In this context, the impulse buying behaviour resulting in negative emotions is the result of negative emotions and unhappiness. On the other hand, there is a necessity to act under ethical and social responsibility principles regarding the purchasing actions and results of the consumers who make purchasing decisions with marketing activities (Torlak, 2007). While 4.5 billion tons of food is produced annually for the world population, which is about 8 billion (Climate Related Transboundary, 2008) and this production amount is expected to be enough to feed 10 billion people, about 1 person out of every 9 in the world cannot be fed enough and is hungry instantly. It raises an ethical problem that individuals who engage in irrational behaviour with their behaviours need to reconsider. There is a need to be regarded by marketers to improve new and contemporary approaches for consumers. In this context, thinking of these individuals who are unhappy because they couldn't meet their physical needs could be expressed as a suggestion to solve this ethical problem while making an irrational, impulsive behaviour to be happy when they feel psychologically unhappy.

This study was carried out in a short period due to time and cost constraints. One of the study's limitations is that the study data were obtained only from the participants in Duzce province. Those who want to study the subject further could develop a research model that includes other factors in the literature that cause individuals' impulse buying behaviours.

Author Contributions: conceptualization, S. A., A. S.; methodology, S. A., A. S.; validation, S. A., A. S.; formal analysis, S. A., A. S.; investigation, S. A., A. S.; resources, S. A.; data curation, A. S.; writing - original draft preparation, S. A.; writing - review and editing, A. S.; supervision, S. A., A. S.

Funding: This research received no external funding. 


\section{S., Ata, A., Sezer. Evaluating the Effects of Life Satisfaction on Impulse Buying Behavior in Terms of Online Buying}

\section{References}

Alagöz, S. B., \& Ekici, N. (2011). Impulse purchasing as a purchasing behaviour and research on Karaman. International Research Journal of Finance and Economics, 66; 172-180. [Google Scholar]

Altunışık, R., Bora, B., \& Sarıkaya, N. (2010). Alışveriş Çıllgınlığı: Tüketici Gözüyle Alışveriş Çılgınlığı Olgusunun İncelenmesi Üzerine Bir Nitel Araştırma. 15. Ulusal Pazarlama Kongresi Bildiri Kitabı, 50-59. Retrieved from [Link]

Altunışık, R., Coşkun, R., Bayraktaroğlu, S., \& Yıldıım, E. (2007). Sosyal bilimlerde araştırma yöntemleri: SPSS uygulamalı. Sakarya yayıncilik. [Google Scholar]

Arnold, M. J., \& Reynolds, K. E. (2003). Hedonic shopping motivations. Journal of retailing, 79(2), 77-95. [Google Scholar [CrossRef]

Aytaç, M., \& Öngen, B. (2012). Doğrulayıcı faktör analizi ile yeni çevresel paradigma ölçeğinin yapı geçerliliğinin incelenmesi. İstatistikçiler Dergisi: Istatistik ve Aktüerya, 5(1), 14-22. [Google Scholar]

Baumeister, R. F., \& Heatherton, T. F. (1996). Self-regulation failure: An overview. Psychological inquiry, 7(1), 1-15. [Google Scholar] [CrossRef]

Baumeister, R. F., \& Vohs, K. D. (2004). Handbook of self-regulation: Research, theory and applications. New York: Guilford Press. Retrieved from [Link]

Bearon, L. B. (1989). No great expectations: The underpinnings of life satisfaction for older women. The Gerontologist, 29(6), 772-778. [Google Scholar] [CrossRef]

Beatty, S. E., \& Ferrell, M. E. (1998). Impulse buying: Modeling its precursors. Journal of retailing, 74(2), 169-191. [Google Scholar] [CrossRef]

Bentley, M. L. (1995). Carpe diem. Science activities, 32(3), 23-27. [Google Scholar] [CrossRef]

Bozdağ Türker, Y. (2019). Parayla Saadet Olur mu?: Kompulsif Çevrimiçi Satın Alma Davranışılya IIIgili Değişkenlerin Incelenmesi ve Bergen Alışveriş Bağımlılı̆ı Ölçeği'nin Türkçe Uyarlanması (Doctoral dissertation, Ankara Yıldırım Beyazıt Üniversitesi Sosyal Bilimleri Enstitüsü). [Google Scholar]

Byrne, B. M. (2010). Testing for the factorial validity of a theoretical construct. Structural equation modeling with AMOS: Basic concepts, applications, and programming, 74-82. [Google Scholar]

Chen, L. (2009). Online consumer behavior: An empirical study based on theory of planned behavior. The University of Nebraska-Lincoln. [Google Scholar]

Çivitçi, A. (2012). Üniversite öğrencilerinde genel yaşam doyumu ve psikolojik intiyaçlar arasındaki ilişkiler. Çukurova Üniversitesi Sosyal Bilimler Enstitüsü Dergisi, 21(2), 321-336. [Google Scholar]

Cobb, C. J., \& Hoyer, W. D. (1986). Planned versus impulse purchase behavior. Journal of retailing. [Google Scholar]

Coley, A., \& Burgess, B. (2003). Gender differences in cognitive and affective impulse buying. Journal of Fashion Marketing and Management: An International Journal. [Google Scholar] [Google Scholar]

Cruice, M., Worrall, L., Hickson, L., \& Murison, R. (2003). Finding a focus for quality of life with aphasia: Social and emotional health, and psychological wellbeing. Aphasiology, 17(4), 333-353. [Google Scholar] [CrossRef]

Dawson, S., \& Kim, M. (2009). External and internal trigger cues of impulse buying online. Direct Marketing: An International Journal, 3(1), 20-34. [Google Scholar] [CrossRef]

Dhaundiyal, M., \& Coughlan, J. (2009). The effect of hedonic motivations, socialibility and shyness on the implusive buying tendencies of the Irish consumer. Irish Academy of Management, 1-29. [Google Scholar]

Diener, E. D., Emmons, R. A., Larsen, R. J., \& Griffin, S. (1985). The satisfaction with life scale. Journal of personality assessment, 49(1), 71-75. [Google Scholar] [CrossRef]

Diener, E., \& Suh, E. (1997). Measuring quality of life: Economic, social, and subjective indicators. Social indicators research, 40(1), 189-216. [Google Scholar] [CrossRef]

Dursun, T., \& Yener, D. (2014). İçüdüsel satınalma ölçeklerinin türk tüketiciler için uyarlanmasına yönelik hazır giyim sektöründe bir uygulama. Electronic Journal of Vocational Colleges, 1(4), 22-31. [Google Scholar] [CrossRef]

Eid, M., \& Larsen, R. J. (Eds.). (2008). The science of subjective wellbeing. Guilford Press. [Google Scholar]

Enginkaya, E. (2006). Elektronik Perakendecilik ve Elektronik Alisveris. Ege Academic Review, 6(1), 11-16. [Google Scholar]

Erdem, Ş., Türkyılmaz, C. A., \& Kırgız, A. C. (2015). Online anlık satın alma davranışlarının hazcı alışveriş motivasyonları ile açıklaması: Hazır giyim ürünleri üzerine bir araştırma. Beykoz Akademi Dergisi, 3(2), 55-74. [Google Scholar] [CrossRef]

Erkan, M. (2012). E-Ticaret Çağı. İstanbul:Optimist Yayınları. Retrieved from [Link]

Food and Agriculture Organization. (2008). Climate Related Transboundary Pests and Diseases. [Google Scholar]

Gamgam, H., \& Ünver, O. (1986). Uygulamalı Istatistik Yöntemler. [Google Scholar]

Gerlevik, D. (2012). İnternet üzerinden alışverişin tüketici davranışı üzerindeki etkisi. Atılım Üniversitesi Sosyal Bilimler Enstitüsü Ișletme Ana Bilim Dalı, Yüksek Lisans Tezi. Ankara. [Google Scholar]

Graa, A., Dani-Elkebir, M., \& Bensaid, M. (2014). The impact of environmental factors on impulse buying behaviour using the Mehrabian and Russell's framework. Leonardo Journal of Sciences, 13(24), 101-114. [Google Scholar]

Hausmann, A. (2000). A Multi-Method Investigation of Consumer Motivations in Impulse Buying Behavior. Joumal of Marketing, 17(5), 403-419. [Google Scholar] [CrossRef]

Hooper, D., Coughlan, J., \& Mullen, M. R. (2008). Structural equation modelling: guidelines for determining model fit. Electron J Bus Res Methods 6, 53-60. [Google Scholar] 


\section{S., Ata, A., Sezer. Evaluating the Effects of Life Satisfaction on Impulse Buying Behavior in Terms of Online Buying}

Howell, D. C. (1987). Statistical Methods for Psychology (2 nd ed.). Boston: PWS-KENT. [Google Scholar

İzi, B. B., \& Şahin, I. (2013). Elektronik perakende sektörü ve internet alişverişi tüketici davranişi: Türkiye örneği. Ekonomi ve Yönetim Araştırmaları Dergisi, 2(1), 9-27. [Google Scholar] [CrossRef]

Johnson, S. B. (2011). "Carpe Diem»-Seizing the Day. Successful Engagement in a Changing Society. Plant Protection Quarterly, 26(3), 103-105. [Google Scholar]

Kline, R. B. (2011). Principles and practice of structural equation modeling (3. Baskı). New York, NY: Guilford. [Google Scholar Köker, S. (1991). Normal ve Sorunlu Ergenlerin Yaşam Doyumu Düzeylerinin Karşılaştıııması (Yayınlanmamış Yüksek Lisans

Tezi). Ankara Üniversitesi Sosyal Bilimler Enstitüsü. Retrieved from [Link]

Korur, M. G., \& Kimzan, H. S. (2016). Kompulsif satın alma eğilimi ve alışveriş sonrası pişmanlık ilişkisinde kontrolsüz kred

kartı kullanımının rolü: avm müșterileri üzerine bir araştırma. Tüketici ve Tüketim Araștırmaları Dergisi, 8(1), 43-71. [Google Scholar] Marsh, H. W., Wen, Z., Nagengast, B., \& Hau, K. T. (2012). Structural equation models of latent interaction. In R. H. Hoyle (Ed.), Handbook of structural equation modeling (p. 436-458). The Guilford Press. [Google Scholar]

Metin, M. (Ed.). (2015). Kuramdan uygulamaya eğitimde bilimsel araştırma yöntemleri. Pegem Akademi. Retrieved from [Link] Miao, L. (2011). Guilty pleasure or pleasurable guilt? Affective experience of impulse buying in hedonic-driven consumption. Journal of Hospitality \& Tourism Research, 35(1), 79-101. [Google Scholar] [CrossRef]

Myers, D. G., \& Diener, E. (1997). La poursuite scientifique du bonheur. Revue québécoise de psychologie, 18(2). [Google Scholar]

Neugarten, B. L., Havighurst, R. J., \& Tobin, S. S. (1961). The measurement of life satisfaction. Journal of gerontology,16, 134-

143. [Google Scholar] [CrossRef]

Özdamar, K. (2013). Paket programlar ile istatistiksel veri analizi (Cilt 1). Ankara: Nisan Kitapevi, 27-36.

Park, E. J., Kim, E. Y., \& Forney, J. C. (2006). A structural model of fashion-oriented impulse buying behavior. Jourmal of Fashion Marketing and Management, 10(4), 433-446. [Google Scholar] [CrossRef]

Park, E. J., Kim, E. Y., Funches, V. M., \& Foxx, W. (2012). Apparel product attributes, web browsing, and e-impulse buying on shopping websites. Journal of Business Research, 65(11), 1583-1589. [Google Scholar] [CrossRef]

Piron, F. (1991). Defining impulse purchasing. ACR North Americould Advances. [Google Scholar]

Piron, F. (1993). A Comparison of Emotional Reactions Experienced by Planned, Unplanned and Impulse Purchasers.

Advances in Consumer Research, 20, 341-344. [Google Scholar]

Rook, D. W. (1987). The buying impulse. Journal of consumer research, 14(2), 189-199. [Google Scholar] [Google Scholar]

Schermelleh-Engel, K., Moosbrugger, H., \& Müller, H. (2003). Evaluating the fit of structural equation models: Tests of

significance and descriptive goodness-of-fit measures. Methods of psychological research online, 8(2), 23-74. [Google Scholar]

Seligman, M. E. (2002). Positive psychology, positive prevention, and positive therapy. Handbook of positive psychology, 2(2002), 3-12. [Google Scholar]

Şener, A. \& Aslan, M. (2019). Money Attitude Among Older Consumer Effect On Consumer Decision Making And Life Satisfaction. International Social Sciences Studies Journal, 5(46), 5365-5371. Retrieved from [Link]

Shichman, S., \& Cooper, E. (1984). Life satisfaction and sex-role concept. Sex roles, 11(3-4), 227-240. [Google Scholar] [CrossRef]

Silvera, D. H., Lavack, A. M., \& Kropp, F. (2008). Impulse buying: The role of affect, social influence, and subjective wellbeing. Journal of Consumer Marketing. [Google Scholar] [CrossRef]

Simon, D., Kriston, L., Loh, A., Spies, C., Scheibler, F., Wills, C., \& Härter, M. (2010). Confirmatory factor analysis and recommendations for improvement of the Autonomy-Preference-Index (API). Health Expectations, 13(3), 234-243. [Google Scholar] [CrossRef]

Smith, T. E., Richards, K. V., Shelton, V. M., \& Malespin, T. S. (2015). Sirens' call: Understanding poor financial decision making and credit card misuse. Journal of Human Behaviour in the Social Environment, 25(8), 897-906. [Google Scholar] [CrossRef]

Solomon, M. R. (2003). Tüketici krallığının fethi. Cev., Selin Cetinkaya, MediaCat Yayınları, İstanbul. [Google Scholar]

Stern, H. (1962). The significance of impulse buying today. Journal of marketing, 26(2), 59-62. [Google Scholar] [CrossRef

Tatılıdil, R., Zalluhoğlu, A. E., \& Candemir, A. (2012). Mobil Perakendecilik ve Tüketici Eğilimlerinin Analizine Yönelik Bir Pilot

Çalışma. 11. Ulusal İşletmecilik Kongresi. [Google Scholar]

Tice, D. M., Bratslavsky, E., \& Baumeister, R. F. (2001). Emotional distress regulation takes precedence over impulse control: If you feel bad, do it!. Journal of personality and social psychology, 80(1), 53. [Google Scholar] [CrossRef]

Torlak, Ö. (2007). Pazarlama ahlakı (4. Baskı). İstanbul: Beta Yayınları. [Google Scholar]

Vasseur, M. F. (2011). Carpe Noctem: Social Media and the Sharing of the Night Skies (Doctoral dissertation, Universite d'Ottawa/University of Ottawa). [Google Scholar] [CrossRef]

Verplanken, B., \& Herabadi, A. (2001). Individual differences in impulse buying tendency: Feeling and no thinking. European Journal of personality, 15(1), 71-83. [Google Scholar] [CrossRef]

Verplanken, B., \& Sato, A. (2011). The psychology of impulse buying: An integrative self-regulation approach. Journal of Consumer Policy, 34(2), 197-210. [Google Scholar] [CrossRef]

Virvilaitè, R., Saladienè, V., \& Žvinklytè, J. (2011). The impact of external and internal stimuli on impulsive purchasing. Ekonomika ir vadyba, (16), 1329-1336. [Google Scholar]

Weinberg, P., \& Gottwald, W. (1982). Impulsive consumer buying as a result of emotions. Journal of Business research, 10(1), 43-57. [Google Scholar] [CrossRef] 


\section{S., Ata, A., Sezer. Evaluating the Effects of Life Satisfaction on Impulse Buying Behavior in Terms of Online Buying}

Weun, S., Jones, M. A., \& Beatty, S. E. (1998). Development and validation of the impulse buying tendency scale. Psychological reports, 82(3), 1123-1133. [Google Scholar] [CrossRef]

Willis, S. (1991). Gündelik Hayat Klavuzu (Çev. Aksu BORA, Asuman EMRE). İstanbul: Ayrıntı Yayınları. [Google Scholar]

Wood, M. (1998). Socio-economic status, delay of gratification, and impulse buying. Journal of economic psychology, 19(3), 295-320. [Google Scholar] [CrossRef]

Youn, S., \& Faber, R. J. (2000). Impulse buying: its relation to personality traits and cues. Advances in consumer research, 27, 179-185. [Google Scholar]

Yu, C., \& Bastin, M. (2010). Hedonic shopping value and impulse buying behaviour in transitional economies: A symbiosis in the Mainland China marketplace. Journal of Brand Management, 18(2), 105-114. [Google Scholar] [CrossRef]

Серхат Ата, Ph.D., Університет Дюздже, Туреччина

Абдулазіс Сезер, Університет Дюздже, Туреччина

Оцінюваня впливу рівня задоволеності життям споживачів на здійснення ними імпульсних онлайн-купівель

Статтю присвячено аналізу поведінки споживачів з точки зору їх імпульсних покупок. Авторами зазначено, що серед низки факторів, які впливають на здійснення імпульсних покупок, особливе місце займає рівень задоволеності життям споживачів. Стрімкий розвиток онлайн-купівель, постійна взаємодія зі споживачем у віртуальному середовищі має значний вплив на якість життя сповживачів. Зважаючи на це, головною метою дослідження стало визначення сили впливу рівня задоволеності життям споживачів на здійснення ними імпульсивних покупок. У рамках статті авторами проаналізовано силу впливу основних факторів, що впливають на прийняття рішень споживачів при здійсненні онлайн та офлайн покупок. Підгрунтям дослідження стали результати анкетування, проведеного у провінції Дзюдже (Туреччина) з березня по травень 2018 року. Для досягнення поставленої мети використано факторний аналіз із використанням моделі структурних рівнянь. За отриманими результатами встановлено негативний взаємозв'язок між рівнем задоволеністю життям та змінними імпульсної покупки (позитивні емоції, конфлікт емоцій, спонтанна поведінка та управління настроєм). Емпіричні розрахунки засвідчили наявність позитивного взаємозв'язку між рівнем задоволеності життям та раціональною поведінкою споживачів, яка розглядається як додаткова змінна імпульсної покупки. Враховуючи отримані результати, авторами обгурнтовано статистично значущий диференційований вплив на поведінку споживачів таких факторів як: позитивні емоцій, спонтанна поведінка, виду покупок та комерційні канали. Отримані результати мають практичне значення та можуть бути основою для подальших досліджень щодо визначення впливу інших змінних на імпульсну поведінку. Авторами зазначено, що основними обмеженнями даного дослідження $є$ відносно короткий період анкетування (березень-травень), а також вибірка респондентів ссормовано лише зі споживачів провінції Дзюдже (Туреччина).

Ключові слова: задоволення життям, імпульсивні купівлі, онлайн-шопінг, офлайн-шопінг, комерційні канали. 